\title{
The Pteridophyta of the Kundalila Falls, Zambia
}

\author{
JAN KORNAŚ
}

Institute of Botany, Jagiellonian University of Kraków

(Received: May 22, 1974).

This paper is respectfully dedicated to Professor Josias Braun-Blanquet on the occasion of his 90th birthday, 3rd August 1974.

\section{Abstract}

40 species of Pteridophyta occur at the Kundalila Falls, near Serenje in the Central Province of Zambia. Many of them have disjunct geographical distributions. Hygrophilous plant communities of wet rocks and evergreen fringing forests, in which these species grow, seem to represent a relict vegetation type.

The flora of Zambia is relatively poor in ferns and their allies: only 126 species of Pteridophyta have been listed from this country by Schelpe (1971). However, their actual number is somewhat higher; 10 additional species ${ }^{1}$ have been collected recently and further finds are to be expected in future. Nevertheless, these figures still remain much below the numbers of Pteridophyta known to occur in the humid parts of Africa (e. g. in West Tropical Africa: 270 species, Alston 1959). This is certainly due to the unfavourable climatic regime of moderate rainfall and severe dry seasons to which Zambia is subjected.

Until recently very little was known about the geographical distribution and habitat preferences of ferns and their allies on Zambian territory. The author was

${ }^{1}$ Arthropteris monocarpa (Cordem.) C. Chr., Asplenium pumilum Sw. subsp. hymenophylloides (Fée) Schelpe, Azolla nilotica Decne. ex Mett. in Kotschy et Peyr., Cyathea manniana Hook. in Hook. et Bak., Lycopodium verticillatum L. f., Microgramma lycopodioides (L.) Copel., Pellaea calomelanos (Sw.) Link, Pleopeltis macrocarpa (Bory ex Willd.) Kaulf., Selaginella mittenii Bak., Thelypteris madagascariensis (Fée) Schelpe (Kornaś, 1974). 
able to gain detailed personal information on this matters during his stay in Zambia between 1971 and 1973. Thus, the following general conclusions result. Pteridophyta are obviously much more abundant in the higher rainfall areas of the northern parts of the country. They gradually disappear towards the drier South, and very often attain the limits of their distribution because of the increasing continentality of the climate.

Ferns very seldom grow in the dry and open savanna woodlands which cover vast areas of Zambia, and are believed to be the zonal vegetation type in most parts of the country (Keay 1959, White 1968, Fanshawe 1971). Winter droughts, bush fires, and the development of a more or less dense grass cover during the rains seem to be responsible for this situation. That is why in Zambia Pteridophyta are usually limited to non-zonal vegetation types of special habitats, such as rocks, river banks, swamps, waters, etc., and occur often - especially near their distributional limits - in isolated local populations of very limited size. Most impressive colonies of Pteridophyta are to be found near waterfalls, e. g. in the famous "rain forest" at the Victoria Falls (Wild 1964). There are more such examples, scattered all over the country but little studied till now. One of the most interesting among them are the Kundalila Falls, near Serenje in the Central Province.

The Kundalila Falls $\left(13^{\circ} 09^{\prime} \mathrm{S}, 30^{\circ} 42^{\prime} \mathrm{E}\right.$, altitude ca. $1410-1475 \mathrm{~m}$.) are situated on the Central African Plateau near its eastern edge (the Muchinga Escarpment), in an area of great scenic beauty, protected since 1964 as a National Monument. The Kaombe, a small but permanent river, falls here some $65 \mathrm{~m}$. over quarzites and granitic rocks and continues down through a narrow gorge. Constantly sprayed cliffs at the foot of the falls are covered with luxuriant herbaceous vegetation; further down, a narrow fringe of evergreen riparian forest extends into the gorge. Another interesting type of habitat - a permanently wet grassland ("dambo") — is situated in a shallow depression along the river just above the falls. The narrow fringe of stunted riparian forest, growing in the centre of this depression and undoubtedly affected by the frequent formation of mist over the moist grassland, is particularly rich in epiphytes: lichens, ferns, and orchids.

The following 40 species of Pteridophyta have been noted at the Kundalila Falls during three successive visits on 17th January, 1972, 4th-6th May, 1972, and 3rd-5th February, 1973 (the nomenclature is taken from Schelpe 1971; the altitudes refer to sea level; ep.=epiphyte):

1. Dry and sunny rocks above the falls, ca. $1500 \mathrm{~m}$.; Cheilanthes inaequalis (Kunze) Mett. var. inaequalis (crevices), Pellaea pectiniformis Bak. in Hook., Selaginella dregei (C. Presl) Hieron. (bare sandy soil over rocks).

2. Permanently wet dambo grassland above the falls, ca. $1500 \mathrm{~m}$.: Lycopodium carolinianum L. var. grandifolium Spring (bare peat), Thelypteris confluens (Thunb.) Morton.

3. Mist-affected evergreen riparian forest surrounded by dambo grassland above the falls, ca. 1500 m.: Asplenium theciferum (Kunth) Mett. var. concinnum (Schrad.) Schelpe (ep., very abundant), Asplenium aethiopicum (Burm. f.) Becherer coll. (ep., also on boulders), Asplenium protensum Schrad. (ep., on trunk bases only), 
Loxogramme lanceolata (Sw.) C. Presl (ep.), Pleopeltis excavata (Bory ex Willd.) Sledge (ep.), Osmunda regalis $\mathrm{L}$.

4. Rocky slopes in open savanna woodland ("miombo"), ca. 1400-1500 m.: (a) dry places - Pellaea longipilosa Bonap., Pteridium aquilinum (L.) Kuhn in Von Deck. subsp. aquilinum, Pteridium aquilinum (L.) Kuhn in Von Deck. subsp. centrali-africanum Hieron.; (b) slightly humid spots - Anemia angolensis Alston, Arthropteris orientalis (J. F. Gmel.) Posthumus, Aspidotis schimperi (Kunze) P.-Sermolli, Mohria caffrorum (L.) Desv., Nephrolepis undulata (Afz. ex Sw.) J. Sm. in Curt.; (c) humid crevices in rocks - Athyrium schimperi Moug. ex Fée, Mohria lepigera (Bak.) Bak., Selaginella mittenii Bak.

5. Wet rocks in the spray zone under the falls, ca. 1410 m.: Selaginella mittenii Bak. (dominant), Selaginella abyssinica Spring, Asplenium aethiopicum (Burm. f.) Becherer coll., Asplenium protensum Schrad., Cheilanthes farinosa (Forsk.) Kaulf., Cyathea thomsonii Bak., Oleandra distenta Kunze, Trichomanes pyxidiferum L. var. melanotrichum (Schlechtend.) Schelpe.

6. Evergreen forest in the spray zone, 1410 m.: Asplenium protensum Schrad. (dominant on boulders, also as epiphyte on shrubs and trees), Asplenium theciferum (Kunth) Mett. var. concinnum (Schrad.) Schelpe (ep.) Cheilanthes farinosa (Forsk.) Kaulf. (ep.), Loxogramme lanceolata (Sw.) C. Presl (ep.), Pleopeltis macrocarpa (Bory ex Willd.) Kaulf. (ep.), Cyathea thomsonii Bak.

7. Evergreen riparian forest not affected by spray, ca. $1360-1400 \mathrm{~m}$.: Adiantum capillus-veneris L., Asplenium formosum Willd. in L. (on boulders and fallen logs), Asplenium protensum Schrad. (on boulders; reduced specimens only), Doryopteris concolor (Lang. et Fisch.) Kuhn in Von Deck. coll., Elaphoglossum spathulatum (Bory) Moore (on boulders), Elaphoglossum sp. (2 unidentified species), Osmunda regalis L., Pellaea doniana J. Sm. ex Hook., Pleopeltis macrocarpa (Bory ex Willd.) Kaulf. (ep.) Pteris catoptera Kunze var. catoptera, Thelypteris dentata (Forsk.) E. St. John var. dentata (swampy soil), Thelypteris friesii (Brause) Schelpe (swampy soil), Trichomanes pyxidiferum L. var. melanotrichum (Schlechtend.) Schelpe (on boulders).

8. Forest edge, ca. $1360-1400$ m.: Athyrium schimperi Moug. ex Fée, Dryopteris inaequalis (Schlechtend.) Kunze var. inaequalis, Thelypteris cfr. chaseana Schelpe.

9. Discontinuous fringe of tree ferns along a small tributary river, ca. $1360-$ 1400 m.: Cyathea dregei Kunze.

The concentration of Pteridophyta at the Kundalila Falls is quite unusual for this part of Zambia. The abundance of epiphytes is particularly striking; nearly all of them are strictly limited to evergreen forest communities and do not occur in the deciduous savanna woodlands. Most species have their nearest known localities in the Northern and Copperbelt Provinces, at a distance of some $200 \mathrm{~km}$. or more, in evergreen swamp forests ("mushitu") at lower altitudes or in montane forests of higher elevations. In some few cases the nearest known localities are even more distant: ca. $300 \mathrm{~km}$. for Asplenium protensum, and ca. $400 \mathrm{~km}$. for Pteris catoptera var. catoptera. It must be stressed, however, that the flora of the intervening regions 
is little known, and additional finds of the species under discussion may be still expected.

Pteridophyta possess very effective means of dispersal and their isolated populations often result from long distance transport of spores by wind. However, at the Kundalila Falls also some montane Phanerogams with disjunct distributions occur (e. g. Alchemilla kivuensis Engl. - the nearest known locality at a distance of ca. $600 \mathrm{~km}$. in Zaïre, Plateau des Marungu, Lisowski and others 1970, Hypericum quartinianum A. Rich. - the nearest known locality at a distance of ca. $480 \mathrm{~km}$. near Mbala, White 1962). All the hygrophilous plant communities at the Kundalila Falls. with their unsually rich assamblage of ferns, have much in common with those of the higher rainfall areas. It seems therefore quite possible that they represent a relict vegetation type which, at one time, was much more widespread. The Pleistocene climatic osccilations, clearly demonstrated in Tropical Africa (cfr. e. g. Lawıon 1963, Clark and van Zinderen Bakker 1964, van Zinderen Bakker 1970), may have been responsible for both - the former xpansion and the present recession of this vegetation. Comprative phytosociological and chorological studies of isolated patches of evergreen forest in various parts of Zambia may contribute very much to a better understanding of this fascinating problem.

\section{REFERENCES}

Alston A. H. G., 1959, The Ferns and Fern-Allies of West Tropical Africa. Crown Agents for Oversea Governments and Administrations, London, pp. 89.

Clark J. D., Zinderen Bakker E. M., van, sr., 1964, Prehistoric culture and Pleistocene vegetation at the Kalambo Falls, Northern Rhodesia. Nature (London) 201: 971-975.

Fanshawe D. B., 1971, The vegetation of Zambia. Republ. Zambia Forest Res. Bull. 7: 1-67.

Keay R. W. J., 1959, Vegetation Map of Africa. Oxford University Press, Oxford. pp. 24.

Kornaś J., 1974, The Pteridophyta new to Zambia. Bull. Acad. Polon. Sci., Sér. Sci. Biol. 22: $713-718$

Lawt on R. M., 1963, Palaeoecological and ecological studies in the Northern Province of Northern Rhodesia. Kirkia 3: 46-77.

Lisowski S., Malaisse F., Symoens J. J., 1970, Plantes rares ou nouvelles pour la flore du Katanga. Bol. Soc. Brot. 44 (2. sér.): 225-244.

Schelpe E. A. C. L. E., 1970, Flora Zambesiaca, Pteridophyta. Crown Agents for Oversea Governments and Administrations, London, pp. 254.

White F., 1962, Forest Flora of Northern Rhodesia. Oxford University Press, Oxford, pp. 455.

White F., 1968, Zambia. pp. 208-215. In: Hedberg I., Hedberg O. (Eds.) Conservation of vegetation in Africa south of Sahara. Acta Phytogeogr. Suec. 54.

Wild H., 1964, A guide to the flora of the Victoria Falls. pp. 141-181. [In:] Fagan B. M. (Ed.) The Victoria Falls. Comission for the Preservation of Natural and Historical Monuments and Relics: Northern Rhodesia, Livingstone.

Zinderen Bakker E. M., van, sr., 1969. Intimations on quarternary palaeoecology of Africa. Acta Bot. Neerl. 18: 230-239.

Author's address:

Prof. Dr. Jan Kornaś

Institute of Botany,

Jagiellonian University,

ul. Lubicz 46

31-512 Kraków, Poland 
Paprotniki wodospadów Kundalila Falls w Zambii

\section{Streszczenie}

W otoczeniu wodospadów Kundalila Falls koło Serenje stwierdzono występowanie 40 gatunków paprotników; wiele $\mathrm{z}$ nich posiada tutaj stanowiska wybitnie izolowane pod względem geograficznym. Higrofilne zbiorowiska roślinne wilgotnych skał i zawsze zielonych lasów galeriowych, w których skupia się największa liczba takich gatunków, mają zapewne charakter reliktowy. 